\title{
Transmitting Values From Past To Future: A Strategic Program Inquiry For Ankara Victory Square (Zafer Meydanı)
}

\author{
Değerlerin Geçmişten Geleceğe Aktarımı: \\ Ankara Zafer Meydanı için Stratejik Program Araştırması
}

Pınar DiNÇ KALAYCl,1 $\odot$ Dilek AYBEK ÖZDEMIR²

\section{ABSTRACT}

Visioning the future of a significant urban space should be done via a thorough inquiry process, a process of decoding the values and meanings that make that urban space unique. Differences between the present/ongoing program and the specific past uses in these spaces display the socio-cultural changes of societies as they also facilitate the sound base for future scenarios. The present study focuses on The Victory Square (Zafer Meydanı), a meaningful urban space located in the city center of Ankara since 1925. Architectural programming is considered as a potential for promoting the values of spaces including urban areas. Accordingly, the present study proposes a 3-step programming model; focusing firstly on the past uses of the square (history), secondly the current conditions of the space (on-site analyses), and finally the value list to which a possible program should be referring (the strategic program). The study proposes a vision statement and considers public use, culture, greenery, flexibility, comfort, ecology, references, and integration as the main values that transmit past uses to future projections for the specific urban space. Recommendations for functional programming, which is one step further, have also been addressed. The 3-step model (historic inquiry, on-site analyses and strategic programming) presented in the study gathers the inquiry process around values, therefore the proposed model consists the originality of the study. Besides, Victory Square has been subject to limited number of research in the field of history up to now, therefore this study was devoted to diagnosing and transmitting the values that this unique space had in history to visionary scenarios and designs.

Keywords: Ankara Zafer Meydanı (Ankara Victory Square); architectural programming; history; urban heritage; urban space.

Ayrıcalıklı kentsel mekanlar için uygun gelecek senaryolarının belirlenmesi, bu mekanları özgün yapan geçmiş zaman değerlerinin çözümlenmesi ile yakından ilişkilidir. Geçmiş kullanımlar ile şimdiki program arasındaki farklılıklar, toplumların sosyokültürel değişimlerinin izlenebilmesinin yanı sıra fiziksel çevreler için gelecek senaryolarını da olanaklı kılmaktadır. Bu çalışma, 1920'li yıllardan bu yana Ankara kent merkezinde önemli bir rolü olan Zafer Meydanı́na odaklanmıştır. Mimari programlama, kentsel çevreler de dahil olmak üzere, mekânsal değerlerin geliştirilmesi disiplinidir, dolayısıyla çalışma üç adımlı bir programlama modeli sunar: meydanın geçmiş kullanımlarına odaklanır (tarih çalışması), mekânın şimdiki durumunu irdeler (yerinde analiz) ve olası bir programın referans olarak kullanacağı değerleri belirler (stratejik programlama). Çalışma, meydan için bir vizyon önermesi sunar ve kamusallık, kültür, yeşil, esneklik, rahatlık, ekoloji, referanslar ve bütünleşme değerlerini kentsel mekânın geçmişini geleceğine bağlayacak temel değerler olarak önerir. Bir sonraki aşama olan işlevsel programlama için de öneriler sunar. Bu çalışmada sunulan üç adımlı programlama modeli (tarih araştırması, yerinde analizler ve programlama), tüm araştırmayı değerlere yönlendirir, bu da öneri modelin özgünlüğünü oluşturur. Zafer Meydanı'nın şimdiye kadar sınırlı sayıda tarih çalışmasının konusu olması nedeniyle bu çalışma, söz konusu kentsel değerin tarihteki özgün değerlerini teşhis etmeye ve bu değerlerin gelecek senaryolarına ve gelecek tasarımlara aktarılmasına adanmıştır.

Anahtar sözcükler: Ankara Zafer Meydanı; mimari programlama; tarih; kentsel miras; kentsel mekan. 


\section{Introduction}

Specific urban spaces, like squares, parks, buildings and districts which have historical importance constitute accumulated memory of cities, citizens, national and international culture. Preserving such places for future generations is a critical issue since they are considered as the living witnesses of traditions (ICOMOS, 1964). Erasing, altering, destroying effects of time and societies may harm the original meaning of places as they may open such areas vulnerable to inappropriate purposes. Therefore, profiling the past uses of places become important in planning / programming, in visioning an appropriate future. Sustaining these places without devaluing their qualities and drawing habitable futures for them require special efforts going further than mere restoration, preservation and renewal studies. Contribution from all sciences and techniques is expected for safeguarding such places (ICOMOS, 1964, Article 2).

Architectural programming, or briefing as it is called in some literature, has been considered as an integral part of building delivery cycle since 1950s. Post-Occupancy Evaluation, Building Performance Research and Evidence-Based Design approaches have been allies of programming studies; all focus on betterment of human-built environment relationships (Hill, Preiser \& Watson, 2012; Preiser \& Vischer, 2005; Hamilton \& Watkins, 2009). Architectural criticism has been addressed to be related with performance evaluations of buildings as well (Preiser et al, 2015). The main goal of architectural programming is stated as; defining expectations both qualitatively and quantitatively. Among the five possible models, the urban, strategic and functional programs are directly related with the formation of main decisions about physical environments whereas fit-out program is related with the layout of interiors and the operational program is about maintenance and management issues (Blyth \& Worthington 2010.a).

Considering the fact that the facility programming approaches at early times (60s) turned their interest from functional issues to values and missions of organizations during 1980s and became architectural programming (Preiser, 1985; Hershberger, 1985; Duerk, 1993; Dinç, 2002), present study proposes the program inquiry and its processes as one of the techniques that might serve safeguarding historic urban environments. A strategic program inquiry for the Victory Square (Ankara-Turkey), one of the urban squares that played important role in the $20^{\text {th }}$ century of Ankara, will be presented. The study aims to exemplify how such programming studies can focus on original meanings of places, meaning transformations/ deteriorations and provide guidance to places to gain back their genuine roles. The study presents a hypothetical strategic program proposal for a valuable national-urban heritage. Investments and actions should be made via comparing such program proposals prepared by different teams to find the most appropriate responses for such places. Thus, the proposal of this research should be considered just as one and the first.

The motive behind focusing on the Victory Square was the current condition of the space; briefly, its lack of popularity, lack of human/pedestrian density, its acting as an enlarged pavement connecting surrounding roads and finally its concrete texture displaying contrast to the pictures in archives and to the park at the opposite side of the boulevard. These basic observations were considered as hindrances in front of a meaningful development and proper functioning of the urban space that take place in the most crowded and busy boulevard of the city center. Considering the fact that, similar spaces in city centers that need regaining their meanings also require specific, thorough and sound decisions. This study presents a specific approach in this frame.

\section{Methodology}

Programming in general: Program document has been considered as the bridge between user/client and designers (Voordt \& Wegen, 2005), as programming is a creative process (Blyth \& Worthington, 2010.b). Writing a program is possible also for the cases the end-user is not known, the client has not defined any expectations yet, instead expecting the programming team to suggest possibilities. For such cases, when the program is not a business contract between the client, programmers and design teams, programming is considered as a tool for problem seeking (Pena, Parshall \& Kelly, 1987), a process that might become flexible, focus more on specific problem areas, therefore consider past and present situations and vision a possible future for the issue at hand.

The Urban Square that needs re-programming: Architectural programming proposal of this study focuses on an urban heritage figure that requires redefinition and a visionary future. Victory Square in Kızılay (Ankara, Turkey) has been a place of urban value since 1920s, representing the newly found Republic's ideals. The Square was proposed as a unity of two symmetrical parks taking place at each side of a boulevard and a monument taking place in the middle, all taking place at the heart of the new capital city. Square's meaning was changed in time as the boulevard was extended, greenery on the boulevard was diminished, the integrity of parks was decomposed and finally, one of the parks was almost fully occupied by buildings. Since the Square was designed in Modern times, it does not represent the main characteristic of conventional squares of old times; the cohesive spatial 
and functional integrity with the surrounding / enclosing buildings (Sitte, C. 1945). Therefore, it is possible to claim that the Square was born vulnerable to deterioration. Camillo Sitte's complaints about the current status of the conventional Medieval and Renaissance squares (Sitte, C., 1945, p.10-11, p.24), their use as vehicle stations, their functional independence from the buildings that dominate/enclose them, their cohesive enclosure being nullified, their inactive presence and finally the moved original statues/sculptures from these areas to museums and to other public places, all indicate that loss of meaning and life is not only a problem of Modern urban squares but all squares are open to negative transformation.

What can be done to protect such valuable places that have heritage value, how can they be preserved for future generations without poorly reviving the past, but by adding values and by revitalizing the public use of old times? The programming approach in this study was designed according to these concerns.

Strategic Brief as a Tool for Developing the Urban Values: Strategic Brief is defined as the "the foundation stone" of the Functional Brief (the next step) since it defines the initial statement of needs, project scope, site constraints, design objectives and essential requirements for the building, all for giving a well-defined problem to design team(s) (Bradley, 2010). Therefore it is a document that transmits clients' and users' needs to design team, sets out the aims, intentions, expectations, parameters and ends/results through which the Functional Brief (designers' response) and the final project can be evaluated against (Blyth \& Worthington, 2010.a). Although (i) vision statement, (ii) objectives, (iii) needs, (iv) expectations, (v) growth and change, (vi) priorities and measures for success and the (vii) decision framework items have been proposed as sample main steps of strategic programming (Bradley, 2010), strategic briefer, on the other hand, has been let free to choose appropriate process and tools in order to form the best knowledge base for setting out a new approach (Katsikakis, 2010). Examining records, surveying existing facilities and interviewing staff have been mentioned as the main techniques that can be used in Strategic Briefing (Blyth \& Worthington, 2010.b).

The approach: Considering literature, this study proposes the following three-steps for defining a meaningful Strategic Brief that stem from the urban heritage value of the chosen urban figure: (i) Decoding past uses, (ii) diagnosing present problems and (iii) defining a vision statement and the value set that can guide further study. The first two steps are devoted to decoding studies; readings on Square's first formation and later transformations appeared and running on-site analyses for discovering Square's current situation, diagnosing the structure of the actual program that runs the

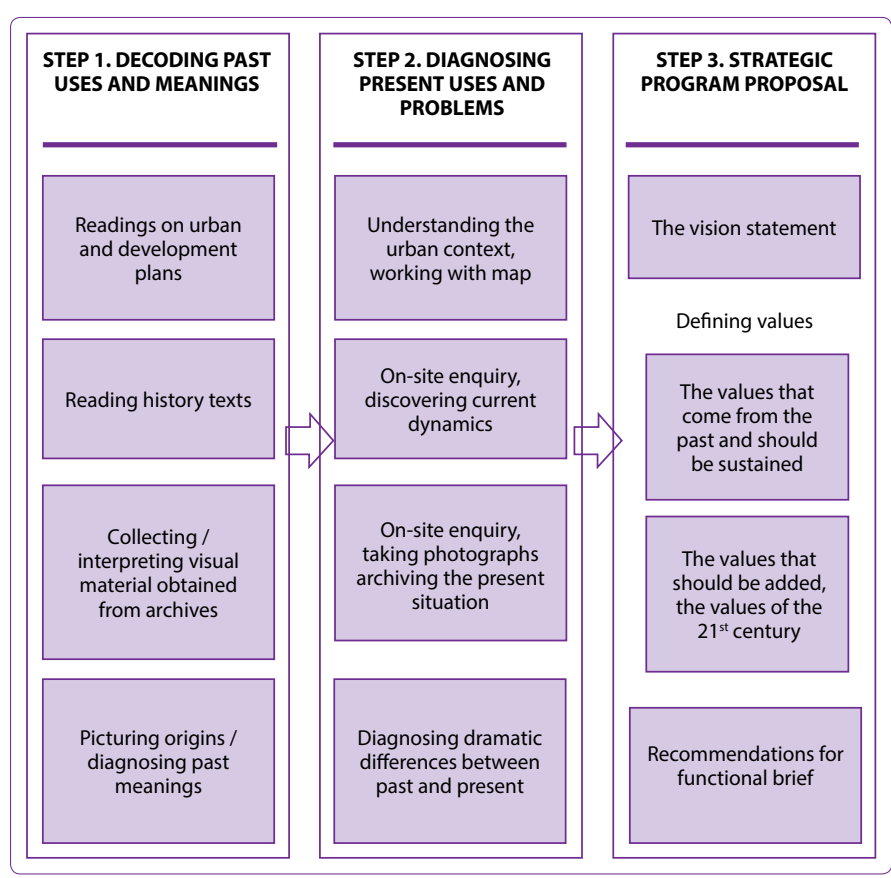

Figure 1. Strategic programming model of the study.

site and the enclosing buildings. The underlying hypothesis for these two inquiries is the following: Victory Square's current condition is far from its past, thus the square lost most of its origins. The final part of the model presents a vision statement aiming at carrying the most valuable parts of past values to the future as it also proposes two sets of values, one set obtained from the inquiry on past and present and the other set projected to future of the Square. The underlying assumption of this process is the following: The Square can regain its value and meaning via effective programming that considers past uses, current complexity and future possibilities in urban and architectural design fields. The proposed program tries to unveil any hidden potentials of the place that stem from its past uses and reactivate them to a certain extent. Therefore, conventional programming steps had to be enriched with history readings. Details of the model operation can be seen in Figure 1.

\section{Victory Square, Past Time}

Urban development of Ankara, the capital city of Turkey, can be observed via the urban and development plans proposed in different years and the unplanned / uncontrollable developments caused by increased population. Therefore, the reading for the Victory Square will be done via considering these two dynamics.

First proposal; a place for gathering and commemoration of national victory: Proposing two interconnected visions for the new and the old city, 1925 Lörcher Plan set the layout and form of the new Boulevard and the squares and parks on it. On the Boulevard (called 
Nation Street in those days), The Victory Square was proposed as an urban space for culture, a gathering place (Ünal, 2015), as the other squares, i.e Sıhhiye, Ulus, Kızılay, Lozan, Cebeci and Tandoğan (Cengizkan, 2002.a; Ercoşkun, 2013; Sarıkulak, 2013), were devoted to different roles in city life. Victory Square took its name from the memory of 30th August 1922, the "Victory Day", thus the Square was the point for refreshing the collective memory of the newly found nation (Cengizkan, 2002.a and c). The Square was designed so that two feet of an arch de triumph, a monumental door structure announcing the victory of the new nation, would be placed on. The symmetric layout of the Square has been interpreted as "a negative door", as the positive door (the crowning monument) which had been designed by Arif Hikmet Koyunoğlu was not built (Cengizkan, 2002.a). Though Lörcher plan was rejected due to several reasons, its public space principles were somehow followed (Ercoşkun, 2013).

Expansion in meaning; the Square becomes a node on the newly established social-natural promenade: 1932 Jansen Plan did not propose a central square but rather followed the main compositional ideas of Lörcher plan (Cengizkan, 2002.c), therefore kept the sequence of small green squares and monuments on the Boulevard. 50 meters width Boulevard was the main axis to which all administrative, social and trade facilities would attach. Though the buildings on each side of the Boulevard were defined as 2-3 floor facilities with gardens in Lörcher plan, this principle did not work for long. Green refuge in the middle, green pavements on sides, coffee houses and patisseries along the Boulevard constituted a socialnatural promenade, a leisure axis (Önder, 2013). The movie theatre Büyük Sinema (the Grand Cinema) with 1550 seats was one of the most important figures on the Boulevard (Önder, 2013). Victory Square was developed as a unity of two symmetrical pocket parks at east-west sides of the Boulevard and the Victory Monument designed by Italian artist Pietro Canonica was placed in the middle, on the axis of the 11 meters wide refuge (Ünal, 2015; Türkyılmaz, 2015; Cengizkan, 2002.b; Kılınç, 2002; Şenyapılı, 1985). The Monument dating back to 1927, depicts a Mustafa Kemal Atatürk appearing in human scale, facing new Parliament building in his military uniform. Both the Square and the Monument were also taking place in the middle of the axis starting with the old city (castle - Ulus) and ending with the new Parliament Building, the spine from where new social life and ideals of new republic could openly be viewed (Batuman, 2002; ilkay, 2009), therefore it had symbolic and representative values as well. Remembrances/biographies and archive photographs related to the Square indicate that sprouting pools and radiant paths connecting these pools to nearby streets had been taking place in each half of the symmetric parks. As time passed, this layout was transformed to more social uses; the east half, called Victory Square today, was characterized by a tea house and its garden. Being full of poplar trees, this garden was creating a distinct node on the Boulevard, especially in summer evenings. The west half, called the Victory Park today, was bordered by an exhibition pavilion (later turned to a single-story bazaar, housing one of the most famous restaurants of the day, The Hale) and a three-story administrative building (Şur'a-yı Devlet) (Memluk, 2009; Cengizkan, 2002.b and c). Pavilion was demolished in 1932 as C. Holzmeister's Military House was built. See Figure 2 (Türkiye Rehberi, 2020, Googlemaps, 2020), 3 and 4.

The Boulevard as business district, time of construction on \& under the Square and fast transformations: With the 1955 Uybadin-Yücel Plan, the new city center Kızılay

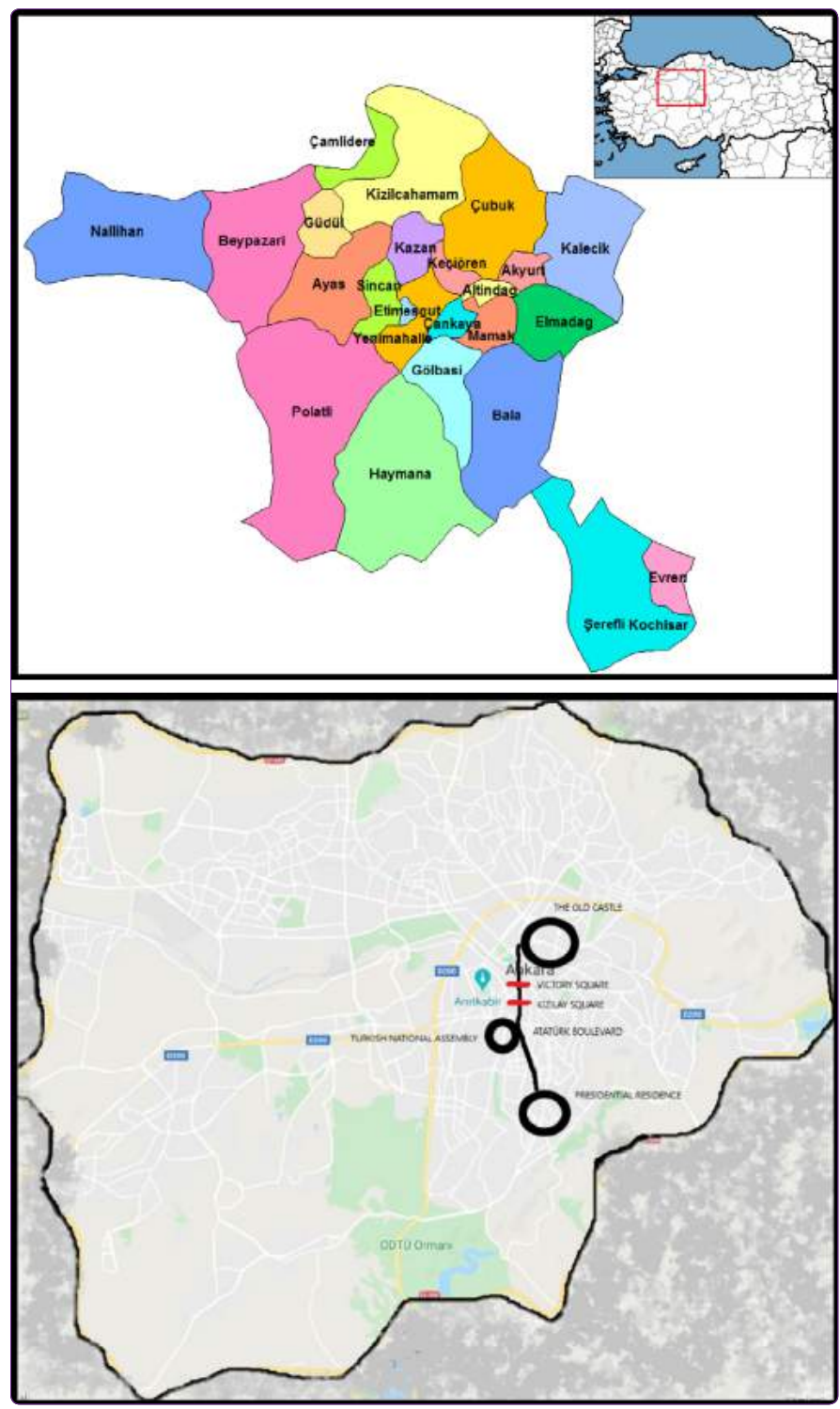

Figure 2. Macroform maps: Ankara in Turkey, Çankaya in Ankara, The Victory Square in relation with other important urban figures in central Çankaya. 
was opened to trade and high population. Permission was given for one extra floor for the buildings on the Boulevard and use of public spaces like squares and parks became less favored (Ünal, 2015). As the Boulevard was also enlarged towards two sides in early 1970s, the green promenade started to lose its quality. Kızılay became the new center for leisure (Önder, 2013) as it started to regain its urban role defined in $30 \mathrm{~s}$ and $40 \mathrm{~s}$; several restaurants, patisseries, clubs and a theater, the Meydan Stage next to the Grand Cinema, started to form the new social life (Önder, 2013). Enlargement of the Boulevard divided the Square into two more definite parts, the Park kept its presence as the Square was opened to transformation through constructions. In 1952, a two-story out-door café, by Emin Onat, was built on the east edge of the Square. The same building was transformed to Turkish Airlines terminal building later. Soon, a shopping center was built under the Square and the terminal building was transformed to a bazaar, without preserving architectural features (Cengizkan, 2002.b and c). All were caused by the redefinition that the plan brought to the Boulevard, it became the Central Business District (Sarıkulak, 2013) whereas constructing an underground garage to the Park was another transformational attempt that was prevented
(Sarıkulak, 2013; Mülkiyeliler Birliği Vakfi, 1988). The three-story administrative building bordering the Park was demolished through the end of 1960s (Cengizkan, 2002.b) as a multi-story Council of State building, by the competition winners Doğan Tekeli \& Sami Sisa, was constructed in 1970s (see Figure 3 and Figure 4).

The Boulevard becoming the metropolitan center and the Square being declined: 1982 Plan introduced alternative development areas connected with the Boulevard as 1990 Development Plan intensified Kızılay's role due to its position between Ulus and Çankaya, the metropolitan center for trade. 2-4 floor buildings had already left their places to 8-9 floor apartment blocks. Spinal role of the Boulevard was strengthened due to the public transport and the underground as both caused an increase in population, human-vehicle flows and subsequent chaos. Role of Kızılay and Boulevard that had been given by Lörcher and Jansen Plans was intensified though meaning was changed dramatically.

2015 and 2023 Ankara Plans were considered neutral either redefining a role for the city center or proposing a meaningful transformation for the Boulevard and the Square (Ünal, 2015). Counsel of State Building bordering

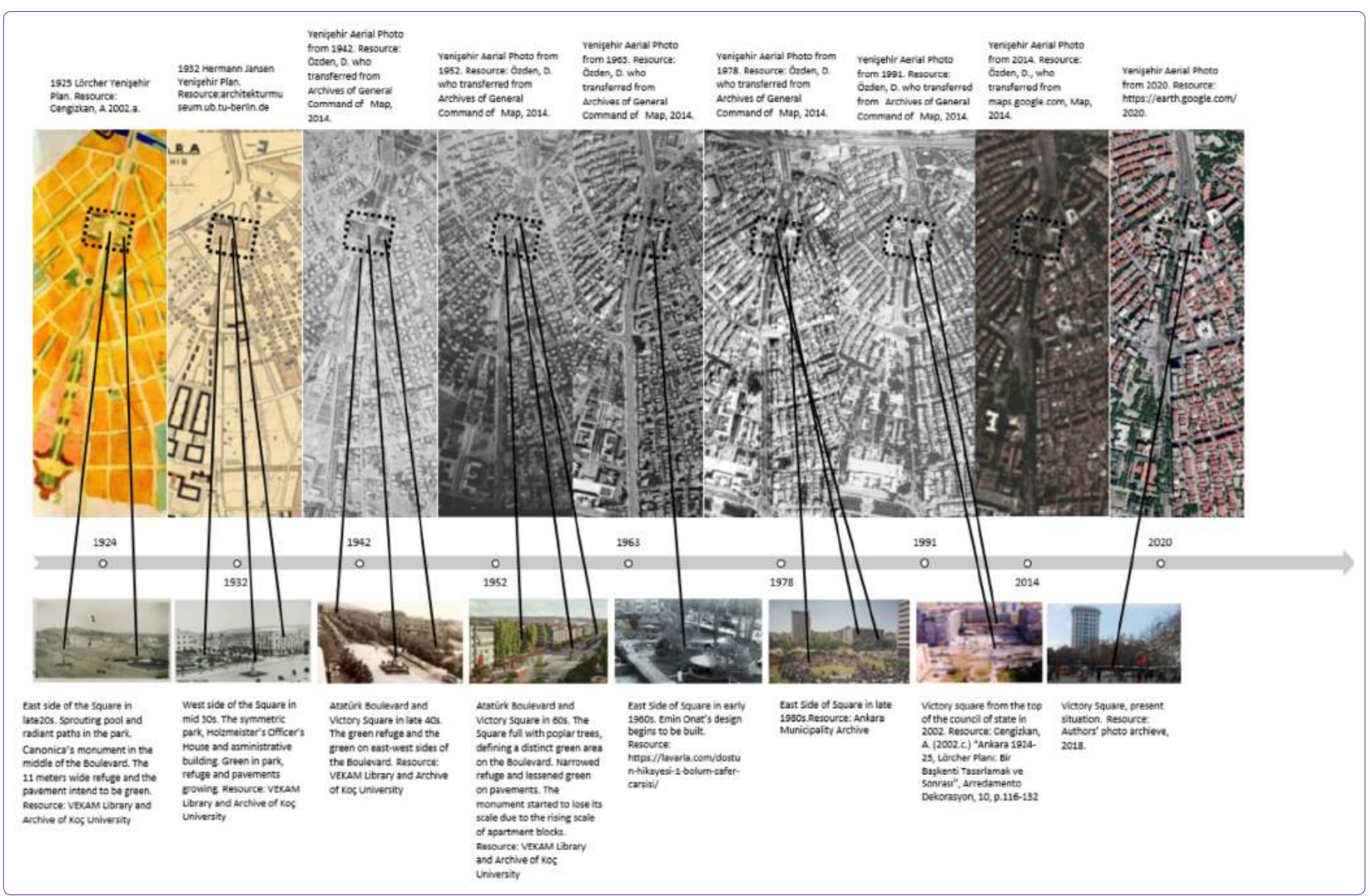

Figure 3. Victory Square Timeline (1920-2020). 

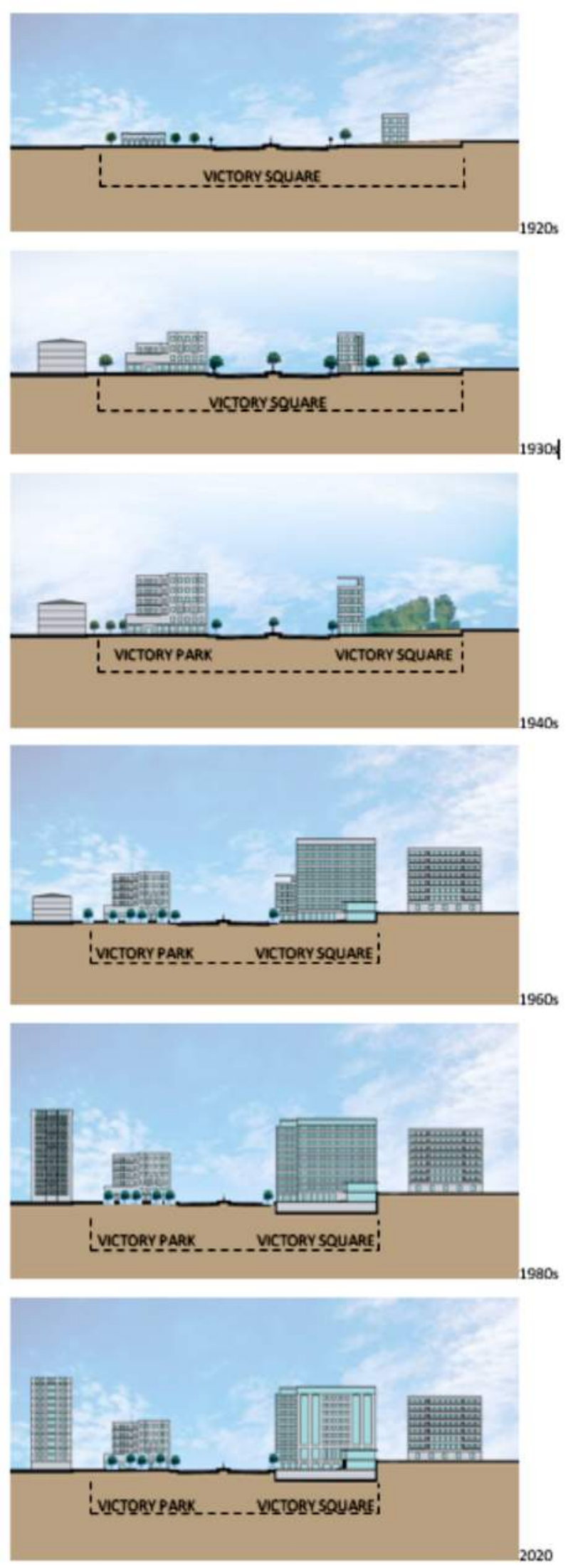

Figure 4. Victory Square Timeline in Sections 1920-2020.

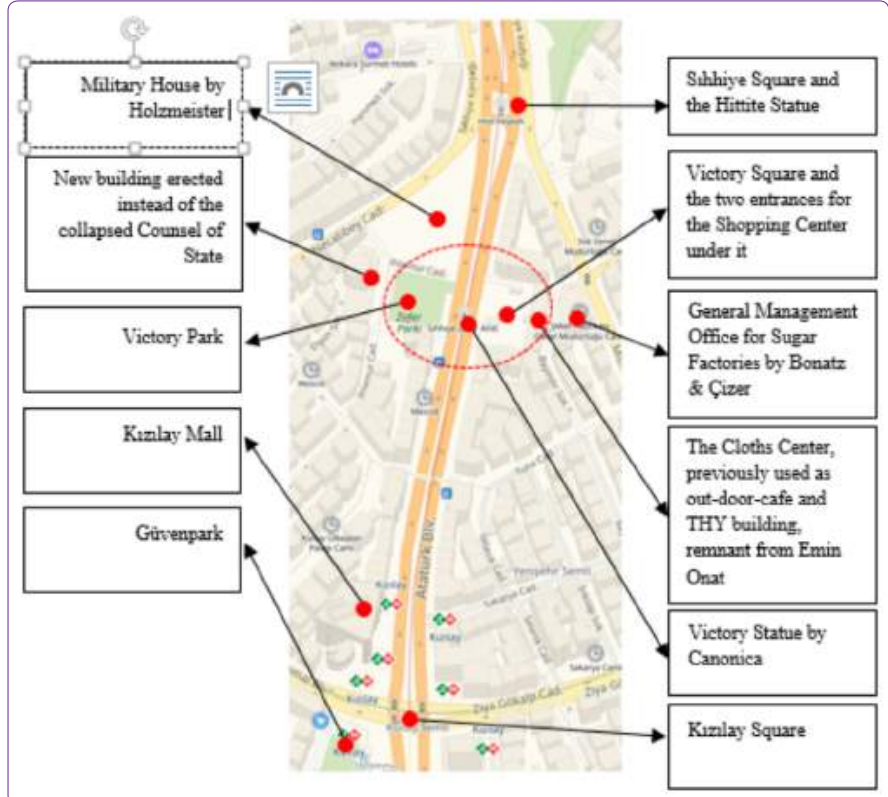

Figure 5. Victory Square, Victory Park and the nearby urban context on the Atatürk Boulevard.

the Park was demolished in 2016; a higher construction has been erected in 2019.

The nearby urban context, the Boulevard (which is still the main axis of the city center containing retail, caterings, offices, shops, passages, hotels, educational facilities, banks, public transport stops, administrative buildings etc.), Kızılay and Sıhhiye Squares (centers for transportation, retail and public spaces), Kızılay Mall (the building that introduced intensive retail and in-door public place to the area), Güvenpark (the major green and open-space transportation hub bordering Kızılay Square) and Abdi İpekçi Park (the major green and public space bordering Sihhiye Square) all propose a heavy pedestrian and traffic load in the area, therefore create opportunity for Victory Square to be a vivid part of the context (See Figure 5). Unfortunately, the situation is the opposite. Therefore, the current situation needs a detailed analysis.

\section{Victory Square, Existing Situation}

Degeneration; reasons and outcomes: 1925 Lörcher New City Plan and 1932 Jansen Plan had proposed Victory Square in form of two symmetrical parks taking place at east-west sides of the Boulevard, as a visual unity, full with green spaces but physically divided into two parts by the road in the middle. By giving Square's width interval to the refuge in the middle, a monument was placed right in the middle of this unity; citizens and bands were given place for gathering at each 30th of August in front of the monument, omitting traffic and turning the whole area to a square housing celebrations and memorial activities. In those days, traffic and human flows were minimal as 
buildings on the Boulevard were low. Basically, three issues concerning proportions and distances had been defining the unique scale and atmosphere of the Boulevard and the Square; (i) proportions of Canonica's monument to the surrounding urban void and to the low building masses around it, (ii) proportions and distances of intensive greens to the building masses and (iii) distances between the building masses taking place in east-west sides of the Boulevard (See Figure 4).

The meaning and use of the Square has been changed in a century's time dramatically due the following reasons; (i) the Boulevard was enlarged due to the increased traffic, (ii) green on each sidewalks and on the refuge was cut due to the enlargement of the Boulevard, (iii) the green in the Square was cut for opening this land to further construction, (iv) the refuge was narrowed and also extended up to the monument, so the urban void and the gathering space around the monument was lost, (v) the population using this area was increased due to the construction of higher and larger blocks around, (vi) the metro stations and their underground shopping constructed in Sihhiye and Kızılay Squares intensified human flow, (vii) the Boulevard became a hub-like transit urban space for the citizens who pass from central Kızılay for moving from one end to the other of the city.

Victory Park and the Victory Square gradually left their central, busy position as all these transformations were happening. Nowadays, the Square is a paved empty space on which entrances to the underground shopping occupies place, as the earlier modernist architecture, Emin Onat's out-door café, turned to a characterless 2 -story building selling cloths. The Park is still green though an important portion of it has been occupied by jerry-built kiosk, sitting units and by the construction of an exit from the underground. Therefore, loss of green and quality as an urban park, occupation of building mass and concretization of ground are, unfortunately, on the agenda for the Park as well.

Heavy traffic on the Boulevard and presence of the underground limits any possibility of Victory SquareVictory Park integrity today. Such impossibility raises the idea of protecting each side independently, preserving the Park as green as possible and reorganizing the Square accordingly so that the unity and green of the old days can be revitalized to a certain extent.

The actual program running Square's enclosure: Victory Square is enveloped by (i) five buildings taking place in surrounding parcels, (ii) one building (Giyim Dünyası) adjacent to the Square, (iii) the underground shopping and (iv) the Boulevard. Proposing a better program for the Square was thought to be possible via a careful reconsideration of existing programs; buildings enveloping the Square were visited and their current programs were decoded. On-site inquiry indicated two buildings being devoted to official-administrative uses whereas other buildings had commercial programs. This principle was kept during programming process since the Boulevard still acts as a spine in the urban structure housing a complex mixture of commercial and administrative buildings.

On-site observations indicate that the Square has been occupied and pulled to pieces by two entrances that connect the Square with the underneath Shopping. One entrance faces the Boulevard pavement as the other takes place in a more subordinate position. The whole Square is like an enlarged pavement, letting passerby's flow from and to the Boulevard. The two-steps cascade in front of the clothes shop, viewing the Square, is a remnant of previous Emin Onat architecture, already lost its originality. Though some of the ground floors of the surrounding buildings are devoted to commerce, the Square is far from attracting people. The concrete pavement of the floor is considered to have a negative effect in creating this emptiness as the Square does not offer any activity, implying standing/ staying. No traces from the old-times greenery were observed, the only greenery appears on the pavement in front. Lower levels of the General Management Office for Sugar Factories, one of the significant Modern architecture figures in the area designed by P.Bonatz and A.M. Çizer in 1954 (Bancl, 2006), has been shaded by the mass of the clothes shop, as the other buildings surrounding the Square does not offer high quality and contemporary architectural compositions. The only architectural value that adds scale and character to the Park-Square unity is the Holzmeister's Officers' House as the newly erected administrative building on the Park side dominates the built environment. A comparison between archive photographs and present situation reveals the added floors to both Holzmeister's and Bonatz \& Çizer's buildings, therefore rise in building heights is valid even for the heritage buildings. Canonica's monument stands alone in the middle of the traffic and the high-raised buildings, lost its context (see Figure 6a and 6b).

The traffic: The current maps of traffic load (Ankara Yoğunluk Haritası, 2020) indicate that the speed in front of the Square is a changing one according to rush hours (See Figure 7). The bus stops in front of the Square and the pedestrian crosswalks in Sihhiye and in front of the Square were observed to have slowing effects whereas the nearby U-Turn for vehicles in Sihhiye Square, the heavy and fast traffic loads in Celal Bayar Boulevard and the Mithatpaşa Boulevard (both traffic and pedestrian roads parallel to Atatürk Boulevard) were thought to have speeding effect. Places of crosswalks, traffic lanes and flow directions, pedestrian bridges, bus stops and nearby metro stations are indicated in Figure 7. As can be observed from 


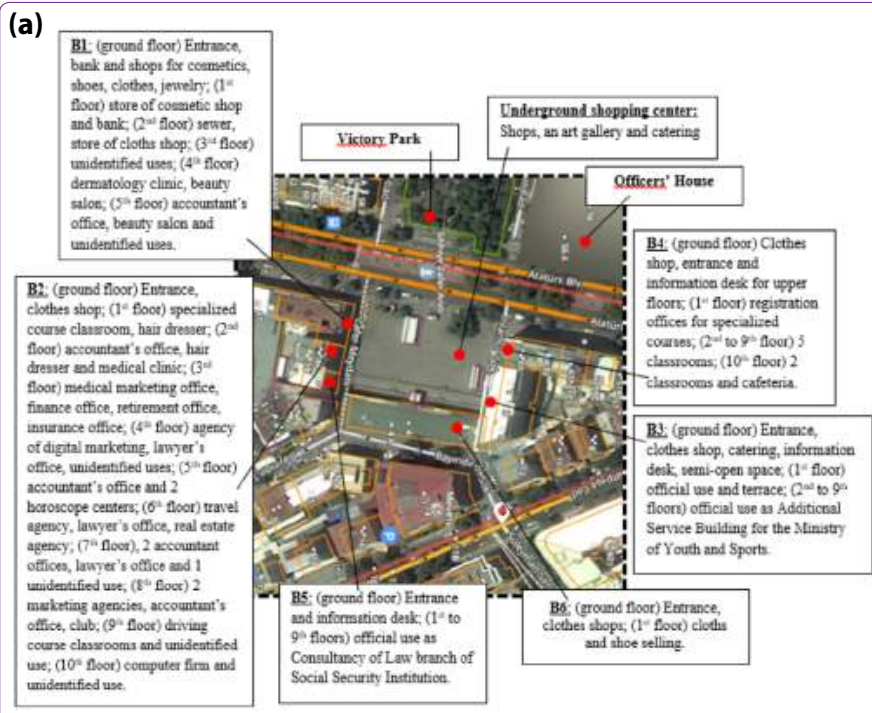

(b)
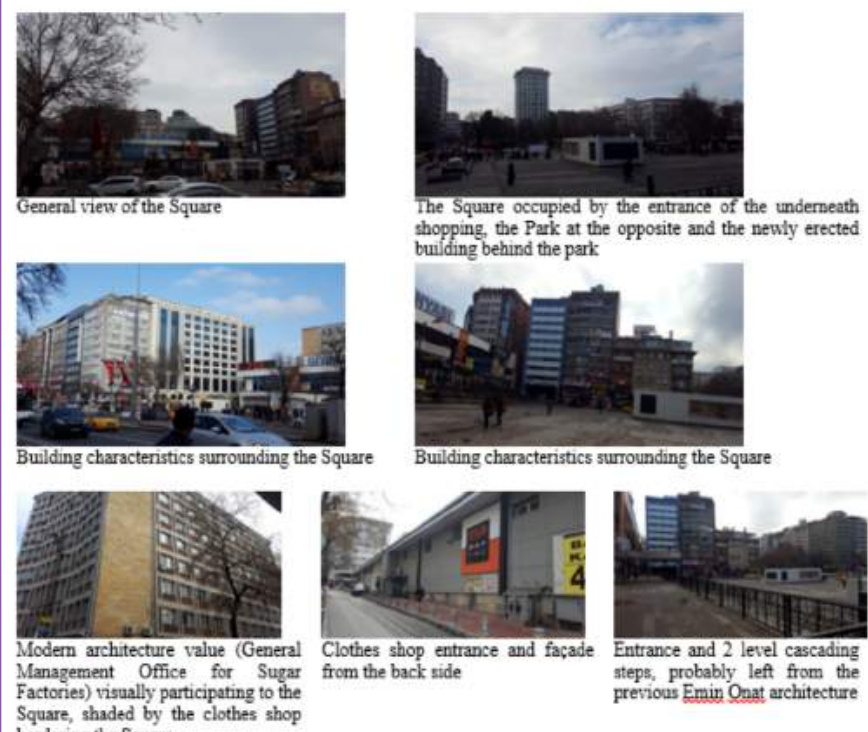

Entrance and 2 level cascading presious Emin Onat archite the bordering the Square

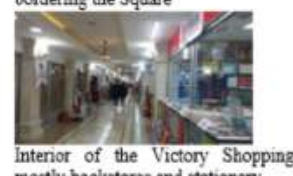

Interior of the Victory Shopping
mostly bookstores and stationary

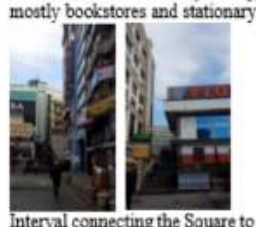

the street behind
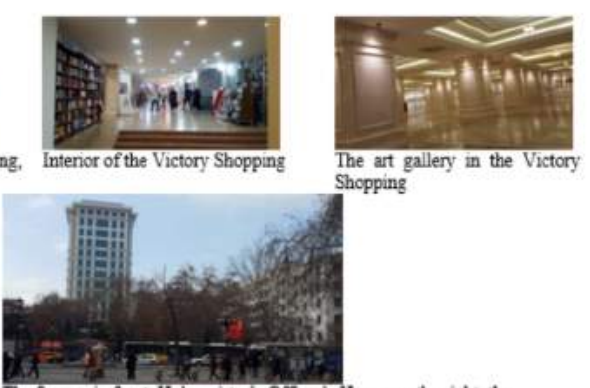

The Square in front, Holrmeister's Officer's House on the right, the Victory Park and the newly erected administrative building

Figure 6. (a) Victory Square and the current uses in enclosing buildings. (b) Victory Square, present situation.

the maps, the Square is on the way of vehicle flows. On the contrary, several public transport stops take place nearby, therefore the Square has the potential of hosting pedestrians, becoming a meeting or short time pausing space for the people who use the Boulevard.

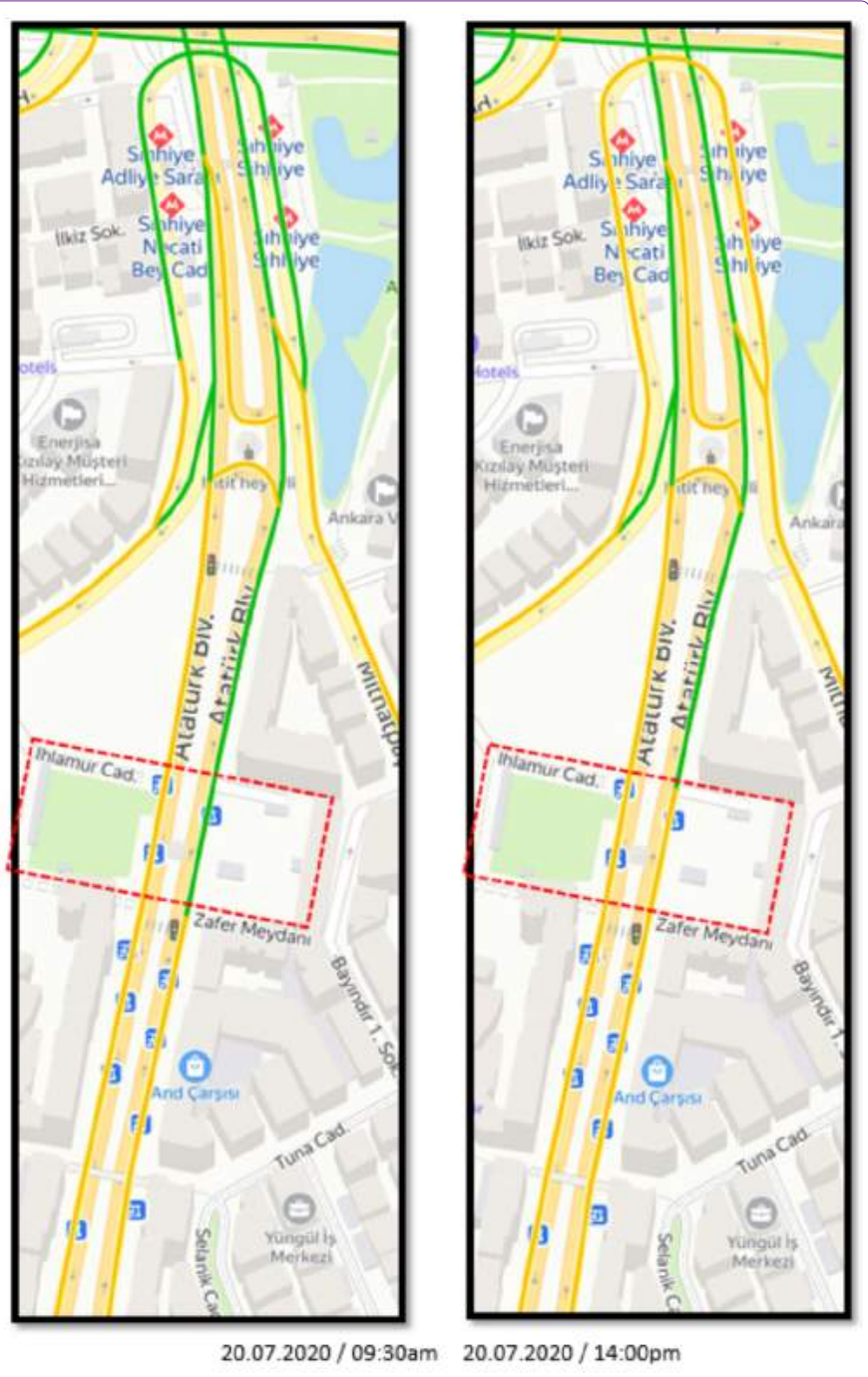

Figure 7. Traffic maps. Green line indicating $45 \mathrm{~km} /$ hour and yellow line indicating $20 \mathrm{~km} /$ hour, red line indicating The Victory Square and the Park.

The climate: January and December are reported to be the coldest (average: $-10^{\circ} \mathrm{C}$ ) and having minimum sunshine (average: $100 \mathrm{hrs} / m o n t h$ ) as July and August are reported to be the warmest (average: $+28^{\circ} \mathrm{C}$ ) and having maximum sunshine (average: $400 \mathrm{hrs} /$ month) in a year in Ankara. Precipitation (rain/snow) is reported to be maximum in May (average: $60 \mathrm{~mm}$ ) and rainy days reach their upper most level in winter, spring and autumn (average 15 days/ month). Similarly, humidity is reported to be around $80 \%$ average during January, February and December (Weather and Climate, 2020). Apart from these average values, extreme conditions such as $+40^{\circ} \mathrm{C}$ in summer, $-20^{\circ} \mathrm{C}$ in winter, heavy rain/snow in spring and autumn, snow standing on the pavement for a month in winter were also observed. The Square is vulnerable to all these climatic challenges as it provides citizens neither with shelter nor with a good quality pavement. 


\begin{tabular}{|c|c|c|c|}
\hline $\begin{array}{l}\text { The vision of } \\
\text { any probable } \\
\text { programming } \\
\text { /design of the } \\
\text { Victory Square } \\
\text { should be } \\
\text { revitalization } \\
\text { of its meaning }\end{array}$ & $\begin{array}{l}\text { PUBLIC USE : The place is a Square, therefore should be able to } \\
\text { invite and encourage public use. Being an empty, monotonous area } \\
\text { surrounded by buildings and traffic, the present Square is far from } \\
\text { attracting people and housing them for purposes like resting, sitting, } \\
\text { demonstration, meeting. organizing social-cultural events, etc. Being an } \\
\text { area for passersby now, the Square should regain its potential for housing } \\
\text { crowds, preferably meeting forlaround leisure, entertainment and cultural } \\
\text { issues. }\end{array}$ & \multirow{4}{*}{$\begin{array}{l}\text { The vision of } \\
\text { any probable } \\
\text { programming } \\
\text { design of the } \\
\text { Victory } \\
\text { Square should } \\
\text { be } \\
\text { revitalization } \\
\text { of fits meaning } \\
\text { via replacing } \\
\text { its passive - } \\
\text { inactive } \\
\text { current status } \\
\text { with a } \\
\text { dynamic- } \\
\text { contemporary } \\
\text { urban square. } \\
\text { This operation } \\
\text { should include } \\
\text { the } \\
\text { surrounding } \\
\text { enveloping } \\
\text { buildings as } \\
\text { well as the } \\
\text { Square's } \\
\text { actual } \\
\text { physical } \\
\text { conditions. } \\
\end{array}$} & 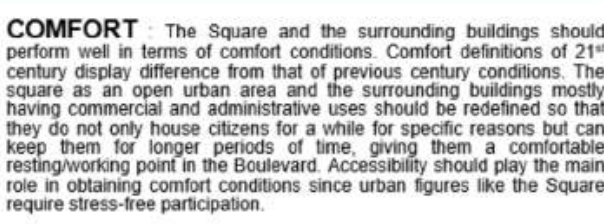 \\
\hline $\begin{array}{l}\text { its passive - } \\
\text { inactive } \\
\text { current status } \\
\text { with a } \\
\text { dynamic- } \\
\text { contemporary } \\
\text { urban square. }\end{array}$ & $\begin{array}{l}\text { GREEN : Considering archive photographs, it is evident that the whole } \\
\text { Boulevard and the Square have lost most of its green. The only green } \\
\text { defining this section of the Boulevard takes place in the Victory Park, the } \\
\text { other side of the traftic road. Any revitalization of the Square should } \\
\text { address adding more green to the field, to the Boulevard and to the } \\
\text { Square, and transforming square for dense public use under and } \\
\text { surrounded with heavy green. An atmospheric / climatic change should be } \\
\text { the theme of all changes. }\end{array}$ & & 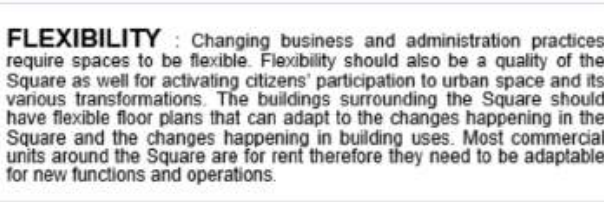 \\
\hline $\begin{array}{l}\text { This operation } \\
\text { should include } \\
\text { the } \\
\text { surrounding/ } \\
\text { enveloping } \\
\text { buildings as } \\
\text { well as the } \\
\text { Square's }\end{array}$ & $\begin{array}{l}\text { CULTURE : Past and current uses indicate "culture" being the main } \\
\text { value associated with the Square. Although the nearby cinema and } \\
\text { theatre had been moved to further streets long time ago, book shops, } \\
\text { second hand book stores, shops selling art materials and art galleries are } \\
\text { still alive in the area. The Square is a unique place on the Boulevard that } \\
\text { has potential for housing "culture" and "the culturar, therefore its } \\
\text { potentials for inviting/housing cultural activities should be considered. } \\
\text { Commercial use should be replaced with culture. }\end{array}$ & & 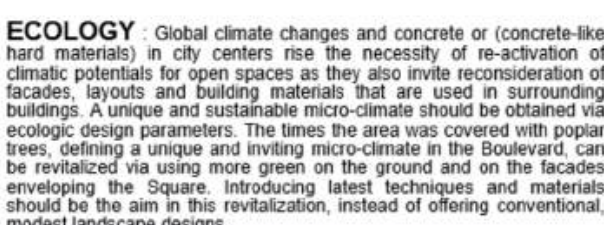 \\
\hline $\begin{array}{l}\text { actual physical } \\
\text { conditions. }\end{array}$ & $\begin{array}{l}\text { INTEGRATION : The Square should integrate with the surrounding } \\
\text { buildings and the other important urban figures that take place nearby. } \\
\text { Therefore, the Ataturk Boulevard, the underground, the Victory Park } \\
\text { Holzmeister's Officers' House, Bonatz \& Cizer's General Management } \\
\text { Office for Sugar Factories, Canonica's monument, Sihhiye and KIzllay } \\
\text { Squares should be the urban figures that revitalization of the Victory } \\
\text { Square should be articulating with. Integration with these figures and } \\
\text { articulation of these urban values, including the Square itself, should be } \\
\text { considered thoroughly. Visitors who experience one of these figures } \\
\text { should naturally be experiencing the other figures of this integrity as well. }\end{array}$ & & 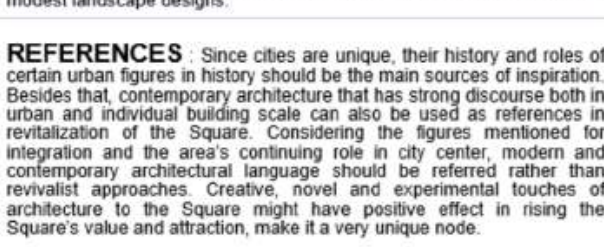 \\
\hline
\end{tabular}

Figure 8. (a) Strategic Brief Part 1: The vision statement and the value set for continuity and healthy revitalization of the Victory Square. (b) Strategic Brief Part 2: The vision statement and the value set for carrying the Victory Square to $21^{\text {st }}$ century.

\section{Strategic Program Proposal}

\section{The Vision Statement}

The term "vision statement" indicates the essence of the project, it sets out the high-level aspirations as it is an objective-based summary of the project and its intentions (Bradley, 2010; Horn, 2010). Considering the dramatic differences between past and current uses of the Square, the vision statement for this urban heritage was formed as the following:

The vision of any probable programming/design of the Victory Square should be revitalization of its meaning via replacing its passive - inactive current status with a dynamic - contemporary urban square. This operation should include the surrounding/enveloping buildings as well as the Square's actual physical conditions.

Current on-under-enclosing programs indicate weaknesses in defining the area as a square. Present Square is more related with commercial and administrative uses around, therefore is like an enlarged transit pedestrian road leading to facilities and connecting roads. This transitory role requires a redefinition since present inquiry indicated that the value of the Square had been the opposite in past. Future of this valuable / unique urban figure can be more meaningful if it is associated with its past meanings and uses and if it is based on contemporary urban considerations. Redefinitions for the enclosing buildings is also necessary in terms of their potential for defining a more meaningful urban environment.

\section{The Value Set; Values For Continuity and Values For $21^{\text {st }}$ Century}

Following the vision statement, considering the highly complex current situation and its distance from original intentions, the value sets displayed in Figure $8 \mathrm{a}$ and $8 \mathrm{~b}$ were proposed. History cannot be the only resource for valuing an urban figure that is located right in the middle of the city center. Values of $21^{\text {st }}$ century should also be addressed for betterment of physical environments. Therefore, the first value set displays the values for continuity and the second indicates the values for $21^{\text {st }}$ century, all together address past, present, and future alike.

This Strategic Brief is proposed as a basement for further Functional briefs and for testing any design proposal that does not stem from a thorough consideration of site and its meaning. As mentioned before, Strategic Brief is a conceptualization of intentions and principles. Before proposing any design or functional program, such Strategic Briefs should be prepared, compared to each other, and assessed according to various criteria such as citizens' values, administrative values, history, economic concerns and architectural preservation issues. Only after deciding for the best Strategic Brief, detailed briefs and designs should be prepared. Considering the literature on the Victory Square, the proposed brief is the only strategic brief 
prepared for the site, thus the present proposal should be assessed as an initial study that may trigger further inquiry and better fitting brief proposals.

\section{Recomendations For Functional Brief}

Being part of iterative design process, Functional Brief is the data-based process in which all performance requirements are defined in detail, each space is expressed in terms of purpose, occupation and use (Horn, 2010). Considering this framework, this Strategic Brief inquiry proposes the following recommendations for possible future Functional Brief studies:

- The Square should be defined as a recreation area based on green areas, encourage resting and performing, and should be able to be used by citizens for 24 hours freely. This necessity stems from the Square's past meaning for the city and citizens. It had been designed as a gathering place, acted as so for a long time despite the rapid transformations. Square's past meaning should be the base for its future.

- Participation of ground floors of the enclosing buildings to the Square should be considered. Enclosure gives definition and life to the Square. Therefore, a vivid square can be possible via the close relationships between the enclosing facilities and the Square.

- The Square should be redefined as a node, free from buildings, letting citizens' free staying, resting, meeting, participation, performance, illustration, demonstration, and exhibition etc. The Square had been a node, therefore should continue being one. That is how it can keep and develop its meaning.

- Visual and functional connections/contacts between the Square and the opposite Park should be established, so the area regains its integrity. As can be noticed in early maps, the unity / integrity of EastWest sides had defined the Square. Unfortunately, the presence of the Boulevard in the middle of sides and its enlargement and intensification in time departed two sides of the composition more. This seems irreversible at the moment unless the main composition of the Boulevard is not changed. For a better and simpler operation of regaining unity, establishing functional and visual contacts can be considered. Adding greenery to the Square may have positive effect in regaining visual integrity.

- Canonica's Monument should find a better position and/or environmental composition, so it can regain the noticeability it deserves. It was Camillo Sitte's complaint that moving statues / sculptures had altering effect on the meaning of places. Therefore, the Monument should be kept, but also should be taking place in a more noticeable composition. Any future design of the Square should also address the Monument.

- The single-story underground shopping that contains an art gallery, cafes and bookstores should be demolished and replaced with a larger complex containing multi-purpose halls, art galleries, restaurants and thematic shops including bookstores. Because the meaning of the place is highly related with gathering, and the underground uses were once introduced to the space, same principles can be united, kept and even further enhanced. An underground complex that has strong connections with the green ground level can be considered. Enclosing facilities can also participate to this operation and underground of the Square can be united with the undergrounds of enclosing buildings. A more complex and total mass can be achieved via combining the Square and its enclosure so that the Square can be defined better. Figure 9 indicates possible uses for enclosing buildings and the space underground.

- The 2-story shopping building and the cascading stairs in front of it should be reconsidered for functional changes. Experts should decide for sustaining/ revaluing the Emin Onat traces on the land. In case of impossibility of sustaining traces, the existing building should be demolished and replaced with a more transparent building (i) containing art-related and cultural uses, (ii) combining the life in the Square to the activities that will take place under the Square and (iii) making the Bonatz \& Çizer design, the General Management for Sugar Factories, more visible.

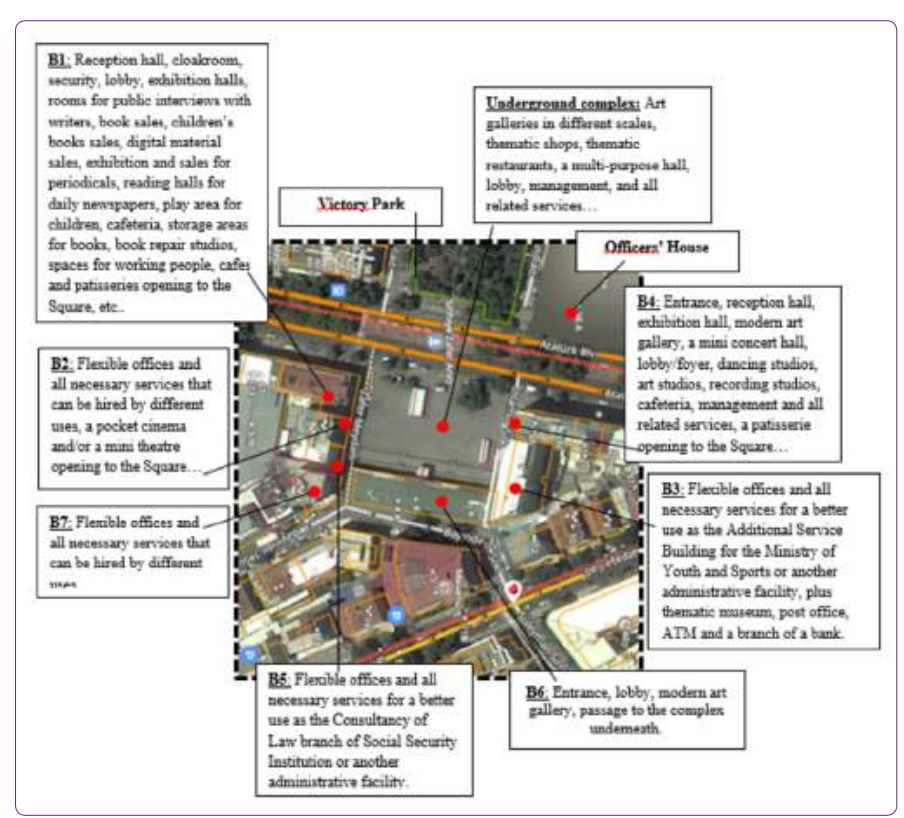

Figure 9. Victory Square and the proposed uses in enclosing buildings. 
- The enveloping buildings that have commercial and administrative uses should be demolished and redesigned in the way proposed in the strategic program so that they can participate in the recreational life in the Square with certain characteristics such as open and semi-open terraces viewing Square and green facades establishing a vertical green background to the Square.

- The commercial uses in enveloping buildings can be minimized so that buildings can host artistic-cultural activities and their related spaces in a better way, which would create a potential for attracting people to the Square. Therefore, uses like art galleries, miniconcert halls, pocket cinemas, dance studios, music and recording studios, mini-theatres, spaces for art courses, thematic museums, libraries, thematic cafes and patisseries should be encouraged.

Proposed uses for each building under, on and surrounding the Square are given in Figure 9. Above recommendations have been based on the historical data and current use observations obtained for the Strategic Brief inquiry; they can be used either for developing a more detailed Functional Brief or for assessing any design proposal that has not been based on research.

\section{Conclusion}

The study is based on the meaning and qualities of an urban heritage. Literature reviews and current situation inquiries displayed the dramatic / negative changes in time, revealed the contrast between current uses, meaning and urban aesthetics with the past. Based on the diagnosed contrast, a vision statement and the values supporting this statement were identified for future operations, as recommendations were clarified for future functional programs.

Areas like Victory Square that acted unique roles in urban history are rare in city centers; therefore special emphasis should be given to their planning, programming and design. The biggest issue related with such areas is the unplanned constructions run by authorities without discussing the urban memory, legacy, values, qualities and potentials of the site. A makeshift conclusion of Necessity becomes the only reference for such operations. Instead, the program alternatives that is respectful to urban memory should be prepared by different teams and these programs should be assessed in terms of contemporary urban discourses such as culture, use, traditions, citizenship, participation, urbanization, demands of the population, urban ecology and sustainability. All development approaches should be assessed in terms of $21^{\text {st }}$-century visions. Obviously, urban design cannot be considered independent from urban memory. Places that have significant memory need special concern in terms of blocking, limiting and regulating all possible unplanned interferences. Therefore, urban design has critical role and value.

Proposing a Strategic Brief for further actions, the present study was conducted as a first attempt. The inactive life in the Victory Square presents a big contrast with the over-active, highly dense daily life continuing in front and around it, therefore requires responsible and effective touches. Transforming this urban value to a more positive status is considered to give impetus for further changes in and around the Boulevard, turn the Square's status from excluded to included. Better integration of the Square with surrounding valuable environment and more participation of citizens to the Square should be obtained via effective programming and creative design respecting Square's genuine values.

The Victory Square was assessed in terms of historical heritage and was declared as "site" (protected area) in 2004 by the Regional Board for Protection of Cultural and Natural Entities of Ankara (Ankara Kültür ve Tabiat Varlıklarını Koruma Bölge Kurulu) as the authorized institution (Municipality of Culture and Tourism, 2012). The reason of this assessment was stated as its presence in 1932 Jansen Plan, its protection in 1955 Uybadin \& Yücel Plan and its survival without change, a statement neglecting the changes and meaning losses diagnosed in this study (Municipality of Culture and Tourism, 2012). Raising consciousness on the reality of such unique places, heritages of nationality and humanity can be possible via the thorough considerations visioning places in history-future integrity. Programming was considered as an appropriate tool for such an approach because of its flexible content. This study should be understood as an attempt uniting programming inquiry and history in terms of experimenting the potentials of architectural programming in contributing safeguarding urban heritage.

\section{References}

Ankara Yoğunluk Haritası (2020) https://ankara.yogunlukharitasi.com/ (Acess: 21.07.2020).

Bancı, S. (2006) "Şeker Şirketi ve Ankara Şeker Fabrikası Yerleşkesi", Dosya 03, TMMOB Mimarlar Odası Ankara Şubesi, Ankara, p. 36-41.

Batuman, B. (2002) "Mekân, Kimlik ve Sosyal Çatışma: Cumhuriyet'in Kamusal Mekânı olarak Kızılay Meydanı", Ed.: Sargın, G. A. (Editor) Ankara'nın Kamusal Yüzleri, Başkent Üzerine Mekân-Politik Tezler, Iletişim Yayınları, i̇stanbul, p. 40-76.

Blyth A., Worthington J. (2010.a) "Articulating the Briefing Process", Managing the Brief for Better Design, Routledge, $p$. 13-25.

Blyth A., Worthington J. (2010.b) "Identifying Needs", Managing the Brief for Better Design, Routledge, p. 25-41.

Bradley, S. (2010) "Strategic Brief", Ed.: Blyth A. and Worthington J. (Editors), Managing the Brief for Better Design Routledge, 
p. 213-223.

Cengizkan, A. (2002.a) 1924-25 Lörcher Planı: Ankara'nın İlk Planı, Arkadaş Yayınları, Ankara.

Cengizkan, A. (2002.b) Modernin Saati, Ankara: Mimarlar Derneği.

Cengizkan, A. (2002.c.) "Ankara 1924-25, Lörcher Planı: Bir Başkenti Tasarlamak ve Sonrası", Arredamento Dekorasyon, 10, p. 116-132.

Dinç, P. (2002) “Problem Araştırmasından Mimari Değerlere Geçişte Bina Programlama" (Building Programming: From Problem Seeking to Architectural Values), Gazi Üniversitesi Mühendislik-Mimarlık Fakültesi Dergisi, 17 (3), GÜMMF, Ankara, p. 101-119.

Duerk, D. (1993) Architectural Programming, Van Nostrand Reinhold Company, New York, USA.

Ercoşkun, Ö.Y. (2013) "Successes and Failiures in Urban Development of Ankara", ICONARP International Journal of Architecture and Urban Planning, 1(2); p. 12-31.

Googlemaps (2020) https://www.google.com.tr/maps/ @39.9033766,32.7627648,11z (Access:21.07.2020).

Hamilton, D.K., Watkins, D.H. (2009) "What is Evidence-Based Design", Ed.: Hamilton, D.K., Watkins, D.H. (Editors), Evidence-Based Design for Multiple Building Types, John Wiley \& Sons, p. 9-18.

Hershberger, R. (1985) "Values: A Theoretical Foundation for Architectural Programming", Ed. Preiser, W.F.E. (Editor), Programming the Built Environment, Van Nostrand Reinhold Company, New York, USA, p. 7-13.

Hill, S.M., Preiser, W.F.E. \& Watson, C. (2012) "Introduction to Building Performance Evaluation: Milestones in Evolution", Ed.: Hill, S.M., Preiser, W.F.E. \& Watson, C. (Editors), Enhancing Building Performance, Wiley-Blackwell, p. 3-18.

Horn, G. (2010) "Functional Brief", Ed.: Blyth A. and Worthington J. (Editors) Managing the Brief for Better Design, Routledge, p. 223-229.

ICOMOS (1964) International Charter for Conservation and Restoration of Monuments and Sites (The Venice Charter 1964), https://www.icomos.org/charters/venice_e.pdf, (Access: 03.01.2019).

Illkay Y. (2009) Politics of Public Space, Political Struggle on and at Kızılay Square with Respect to Perceived, Conceived and Lived Public Space Before and After 1980, Phd Seminar, TU Delft.

Katsikakis, D. (2010) "Strategic Briefing for a Global Organisation", Ed.: Blyth A. and Worthington J. (Editors) Managing the Brief for Better Design, Routledge, p. 187-197.
Kılınç, K. (2002) “Zafer Anıt, Zafer Meydanı ve Ankara'da Kamusallığın Kısa Sürmüş Zaferi Üzerine", Arredamento Dekorasyon, 11, p. 55-58.

Memlük, Y. (2009) Cumhuriyet Devrimi'nin yolu: Atatürk Bulvarı, Ankara: Koleksiyoncular Derneği.

Municipality of Culture and Tourism (2012) Zafer Meydanı ve Zafer Parkı, http://www.envanter.gov.tr/sit/index/detay/38102, (Access: 06.03.2019).

Mülkiyeliler Birliği Vakfi, 1988, Zaferpark Dosyası, Mülkiyeliler Birliği Vakfi Yayınları 6, Ankara.

Önder, D. (2013) Changing Geography of Urban Leisure: The Case of Ankara, unpublished PhD Thesis, Urban and Regional Planning, METU, Ankara.

Pena W., Parshall, S. \& Kelly, K. (1987) Problem Seeking: an Architectural Programming Primer, AIA Press, Washington.

Preiser, W.F.E. (1985) “Introduction”, Ed.: Preiser, W.F.E. (Editor) Programming the Built Environment, Van Nostrand Reinhold Company, New York, USA, p. 1-7.

Preiser, W.F.E., Aaron, T.D., Salama, A.M. \& Hardy, A. (2015) "Introduction", Ed.: Preiser, W.F.E., Aaron, T.D., Salama, A.M. \& Hardy, A. (Editors) Architecture Beyond Criticism, Expert Judgment and Performance Evaluation, Routledge, p. 3-21.

Preiser, W.F.E, Vischer, J. (2005) "The Evolution of Building Performance Evaluation: An Introduction”, Ed.: Preiser W.F.E \& Vischer J. (Editors), Assessing Building Performance, Elsevier, p. 3-13.

Sarıkulak, S. (2013) “Changing Identity of Public Places: Güvenpark in Ankara", Unpublished Master's Thesis, METU.

Sitte, C. (1945) The Art of Building Cities, City Building According to Its Artistic Fundementals, Reinhold Publishing Corporation, NewYork.

Şenyapılı, T. (1985) Ankara Kentinde Gecekondu Gelişimi (19231960), Batkent Konut Üretim Yapı Kooperatifleri Birliği, Ankara.

Türkiye Rehberi (2020) http://www.turkiyerehberi.gen.tr/sehirler/book/export/html/34, (Access:21.07.2020).

Türkyılmaz M. (2015) “Ankara'da Havuzbaşları: 1923-1950”, Ankara Araştırmaları Dergisi, p. 105-136.

Ünal, S.G. (2015) "Kentsel Kamusal Mekânların Dönüşümü: Ankara Atatürk Bulvarı", IV. Türkiye Lisansüstü Çalışmaları Kongresi, Bildiriler Kitabı I, p. 284-305.

Voordt, T.J.M., Wegen, H.B.R (2005) "Programme of Requirements", Architecture in Use, Elsevier, p. 71-107.

Weather and Climate, 2020 https://weather-and-climate.com/ average-monthly-Rainfall-Temperature-Sunshine, Ankara, Turkey (Acess: 21.07.2020). 